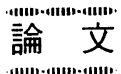

\title{
メルトブロー法によるピッチ紡系の研究
}

松本光昭*, 吉田和雄 $* *$

(平成 4 年 10 月 2 日受理)

\section{Study on Melt-Blowing Process for Coal-Tar Pitch}

\author{
Mitsuaki Matsumoto* and Kazuo Yoshida** \\ *New Materials Division, Nippon Steel Corporation; \\ Present adress: Three-D Composites Research Corp., \\ 2-1-6 Sengen Tsukuba 305, Japan \\ **Plant Engineering \& Technology Center, \\ Nippon Steel Corporation; \\ 20-1 Shintomi, Futtsu City Chiba 299-12, Japan
}

Coal-tar pitch was spun into fiber by melt-blowing method. Nozzles to feed pitch and hot air were arranged concentrically in the die of the spinning apparatus. It was found that the size of diameter of the pitch fiber was strongly influenced by feed rates of pitch and hot air through the die, operating temperature and the diameter of the pitch nozzle, thinner fiber being obtained by applying higher operating temperature. The upper limit of spinnable temperature varried according to the diameter of capillary of the pitch nozzle, smaller diameter of $0.2 \mathrm{~mm} \phi$ of the capillary being able to apply higher temperature. At the optimum operating conditions using $0.2 \mathrm{~mm} \phi$ capillary, pitch fiber having a diameter of $8 \mu \mathrm{m}$ was obtained at pitch-feed rate of $0.167 \mathrm{~g} / \mathrm{min} \cdot$ hole. These results may be superior to take-up roller spinning.

KEYWORDS: Carbon fiber, Melt-spinning, Melt-blowing process, Pitch.

\begin{abstract}
1. 緒言
ピッチ系炭素繊維の商品形態には長繊維と短瀻維があ る。長繊維はプリプレグやフィラメントワインディング 用として利用されるので, 多数本の緎維をいかに無切断 で引き取るかが紡糸技術の重要な課題である。他方短緎 維はコンパンドや断熱材などの沉用品として用いられる
\end{abstract}

* 新日本製鉄(株) 新素材事業本部: 現所属(株)スリー ディンポリサーチ：テ305つくば市千現2-1-6

** 新日本製鉄(株) 設備技術センター：テ299-12 富津 市新富20-1
のでコストが低いことが重要であり，生産性の高い紡糸 法が求められる。長䋐維用の紡糸方法としてはロール引 取法が1)，また短繊維用としては遠心紡糸法2)，メルトブ ロー法が特許で紹介されている。メルトブロー法の特許 としては，互いに角度を持って向かい合ったナイフエッ ジ状ガスノズルによるもの ${ }^{3)}$, 円筒状のガス・ピッチ両 ノズルが同心円状に配置されたノズルを使用するもの4),5) とが紹介されている。しかし研究報告は皆無で技術の詳 細は詳らかでない。本報はメルトブロー法を応用した ピッチの溶融紡糸について研究したものである。

メルトブロー法はノズルから吐出されたポリマーに高 速の熱風を吹きつけ，その風速により細化する。その技 
(a)
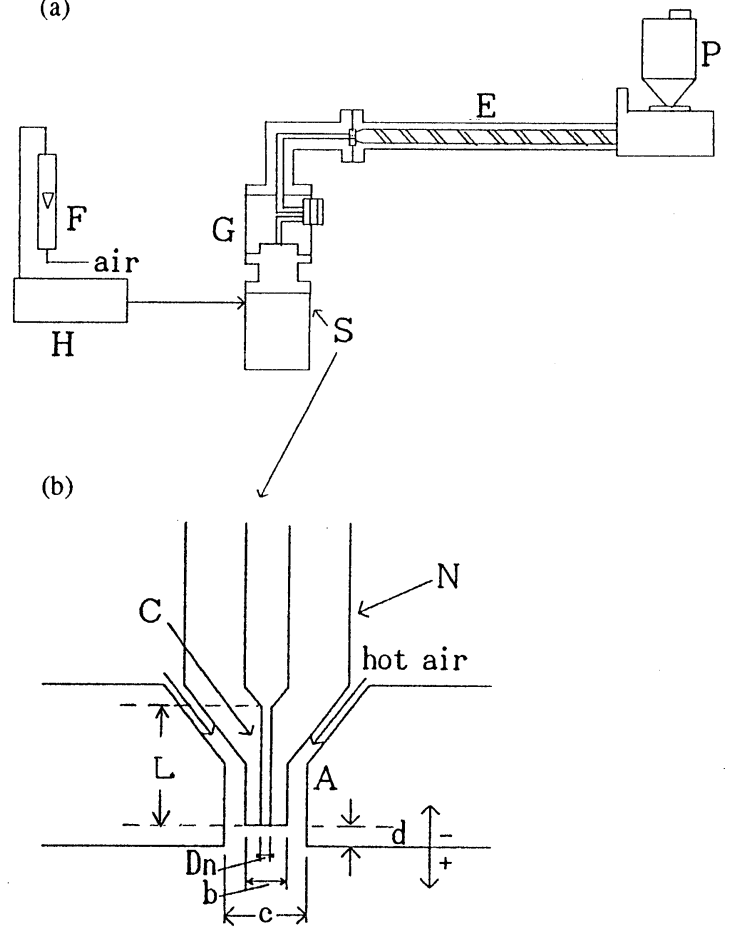

Fig.1 Schematic diagram of melt-blow spinning apparatus
(a) and die (b).
A ; Air nozzle
C ; Capillary
E ; Extruder
F ; Flow meter
$\mathrm{G}$; Gear pump
$\mathrm{H}$; Air heater
$\mathrm{N}$; Pitch nozzle
P ; Pitch holder
S ; Spinning head

Table 1 Dimensions of spinning die.

\begin{tabular}{ccccccc}
\hline die No. & 1 & 2 & 3 & 4 & 5 & 6 \\
\hline $\mathrm{D}_{\mathrm{n}}(\mathrm{mm})$ & 0.3 & 0.3 & 0.3 & 0.3 & 0.2 & 0.2 \\
$\mathrm{~b}(\mathrm{~mm})$ & 1.5 & 1.5 & 1.5 & 1.5 & 1.0 & 1.0 \\
$\mathrm{c}(\mathrm{mm})$ & 2.5 & 2.5 & 2.2 & 2.2 & 2.5 & 2.0 \\
$\mathrm{~d}(\mathrm{~mm})$ & -0.15 & -0.65 & -0.20 & +0.20 & -0.15 & -0.15 \\
$\mathrm{~L}(\mathrm{~mm})$ & 3.0 & 3.0 & 3.0 & 3.0 & 0.8 & 0.8 \\
\hline
\end{tabular}

術はまずエアフィルター用極細纎維の製造技術として開 発され6)，さらに不織布の製造技術としてノズル形状の 改善などが成された7)。そのメカニズムはナイフエッジ 状のガスノズルを互いに向かい合って配置し, そこから
熱風を吹き出し，その会合部にポリマーを吐出して細化 する。繊維をからませる必要からガスノズルは互いに 30 90 の角度を持って配置されている。しかしその角 度がきつくなると糸が切れやすくなる6)。また風速が音 速に達すると糸が切れてショットが出やすくなる8)。

メルトブロー法をピッチ紡系に応用する場合, ピッチ は合瀻に較べて非常に弱いので糸の切断にたいする配慮 がもっとも重要であろう。そこで本研究では音速以下の 風速を用い, またガス, ピッチの流れが平行するよう円 筒状の両ノズルが同心円状に配置されたダイを使って紡 系実験を行い可紡範囲と細化性を調べた。

\section{2. 実験方法}

紡糸実験にはコールタールピッチから製造したキノリ ン不溶分 $(\mathrm{QI})$ を含まない軟化点 $240^{\circ} \mathrm{C}$ 等方性ピッチを 使った。

紡糸装置はFig.1(a)に示すようにピッチ供給部, 熱風 供給部, 紡系へッドから成り, 纎維はチムニーを経て金 網コンベアの上に落下する。紡系ヘッドにはダイ (Fig.1 (b))が100箇直列に並んでおり，鋳达ヒーター(ダイヒー ター)で加熱される。各ダイはピッチノズルとそれを同 心円状に取り用む熱風ノズルから構成されている。ダイ 形状としてはTable 1に示すピッチノズル(キャピラリー 内径 $\mathrm{D}_{\mathrm{n}}$, 外径 $\mathrm{b}$, 長さ $\left.\mathrm{L}\right)$, 熱風ノズル (内径 $\left.\mathrm{c}\right)$, セット バック值 $\mathrm{d}$ を持つもの6種類を用いた。

ピッチを原料ホッパーを経てエクストルーダーに送 り, 溶融・混練し, ギヤポンプで計量して, 吐出量 $\mathrm{W}$ $=1 \sim 3 \mathrm{~kg} / \mathrm{hr}$ (ノズルあたり吐出量 $\mathrm{w}=0.167 \sim 0.5 \mathrm{~g} / \mathrm{min}$. hole)で紡糸ヘッドに供給した。熱風は400kPaの圧縮空 気 $500 \sim 1920 \mathrm{Nl} / \mathrm{min}$ (ノズルあたり熱風量 $\mathrm{q}=5 \sim 19.2 \mathrm{Nl}$ $/ \mathrm{min} \cdot \mathrm{hole})$ を熱風発生装置の電気ヒーターで所定温度に 加熱して紡糸へッドに供給した。ピッチノズルから押し 出されたピッチは, 熱風ノズルから出る熱風で延伸され てピッチ繊維となる。ピッチが纎維状になる範囲をその 条件での可紡範囲とした。ピッチ繊維はノズルから出た 風で搬送され，チムニーを経て $1.5 \mathrm{~m}$ 下の集緎コンベア上 に落下した。繊維径はこのコンベア上のピッチ繊維をサ ンプリングして測定した。

\section{3. 実験結果}

紡糸の状況は温度に応じ概ね次のように変化した。 ピッチがギヤポンプで押し出し得る温度に達すると, 太 いピッチ瀻維が出始め, 温度が上がるにつれて細くなっ た。可紡範囲では繊維はほとんど切れ目のない連続状で あった。糸が切れた場合でも, ロール引取法のように後 続するピッチが太くなって垂れ下がることは無かった。 
Table 2 Velocity and $R e$ of flow of hot air through the die.

\begin{tabular}{ccc}
\hline die No. & Velocity $(\mathrm{Nm} / \mathrm{s})$ & $R e$ \\
\hline 1,2 & 53.2 & 2334 \\
3,4 & 82.0 & 2523 \\
5 & 40.6 & 2668 \\
6 & 70.9 & 3112 \\
\hline
\end{tabular}

(Calculated at $\mathrm{q}=10 \mathrm{Nl} / \mathrm{min} \cdot$ hole, $\mathrm{T}=290{ }^{\circ} \mathrm{C}$ )

これはピッチ吐出口と率引力のかかる位置が同じ点にあ るので, 切れた場合でも後続するピッチが直ちに延伸さ れる事に起因すると考えられる。繊維はランダムな形状 でコンベア上に積み重なった。したがってこの緎維は ロール引取法による長繊維のような用途には向かず，切 断して短織維として用いられるであろう。温度が高すぎ る場合ノズル直下でさみだれ状になり，ピッチ玉(ショ ット)として落下した。代表的な紡系条件として $290^{\circ} \mathrm{C}$, $\mathrm{q}=10 \mathrm{Nl} / \mathrm{min} \cdot \mathrm{hole}$ で計算した熱風のレイノルズ $(R e)$ 数は Table 2のようであった。ここで風速は風量をFig.1(b)の $\mathrm{b}$ と $\mathrm{c}$ 間の熱風通路の断面積 $\mathrm{A}_{1}$ で割った值を使った。 この表から実験条件における熱風のノズル内の流れは層 流〜遷移領域にあったと推察される。

つぎにピッチノズル外径 $\mathrm{b}$, 熱風ノズル内径cの異な る4種のダイ(Table 1, No.1，3，5，6)の紡糸性をしらべ た。 $\mathrm{w}=0.5 \mathrm{~g} / \mathrm{min} \cdot \mathrm{hole} の$ 紡糸実験では，No.6たけは熱風 量, 熱風温度を変えても安定した紡糸ができなかった。 No.6のダイはRe数がもっとも大きいことから熱風の流 れが乱れて紡系ができなかったと考えられる。

ピッチノズルおよび熱風ノズルの先端位置間の距離 $\mathrm{d}$ (セットバック值)を変えた紡糸実験の結果はFig. 2のよ うになった。 $\mathrm{d}=-0.2 \mathrm{~mm}$ と $+0.2 \mathrm{~mm}(\times$ と○) および $\mathrm{d}=-$ $0.15 \mathrm{~mm}$ と $-0.65 \mathrm{~mm}$ (○と口)の各組について比較する と，いずれも紡系性は類似しておりセットバック值は紡 系性にほとんど影響しないことが判る。

つぎに熱風量，風速の影響を Fig.2 $6.5 \mathrm{Nl} / \mathrm{min} \cdot \operatorname{hole}(X, \bigcirc), \mathrm{c}=2.2 \mathrm{~mm} \mathrm{q}=10.0 \mathrm{Nl} / \mathrm{min} \cdot$ hole $(\triangle), \mathrm{c}=2.5 \mathrm{~mm} \mathrm{q}=10.0 \mathrm{Nl} / \mathrm{min} \cdot \operatorname{hole}(\diamond, \square)$ で比較す る。ともに $\mathrm{q}=10.0 \mathrm{Nl} / \mathrm{min} \cdot \operatorname{hole} の(\triangle)$ と $(\diamond, \square)$ は類似 した結果であるが, $\mathrm{q}=6.5 \mathrm{Nl} / \mathrm{min} \cdot \operatorname{hole}(\times, \bigcirc)$ は繊維径 が太く, 牽引力が弱いことが判る。計算では断面積 $\mathrm{A}_{1}$ あ たりの風速は $\mathrm{c}=2.2 \mathrm{~mm} \mathrm{q}=6.5 \mathrm{Nl} / \mathrm{min} \cdot \operatorname{hole}(X, \bigcirc)$ と $=2.5 \mathrm{~mm} \mathrm{q}=10.0 \mathrm{Nl} / \mathrm{min} \cdot \operatorname{hole}(\diamond, \square)$ が等しいが, この 結果によると㐮引力は風速でなくむしろ風量で支配され ることが判った。

つぎにピッチノズルのキャピラリー内径 $\mathrm{D}_{\mathrm{n}}$ の影響をダ イ No.1(0.3mm) およびNo.5 $(0.2 \mathrm{~mm})$ で比較した。両ダイの

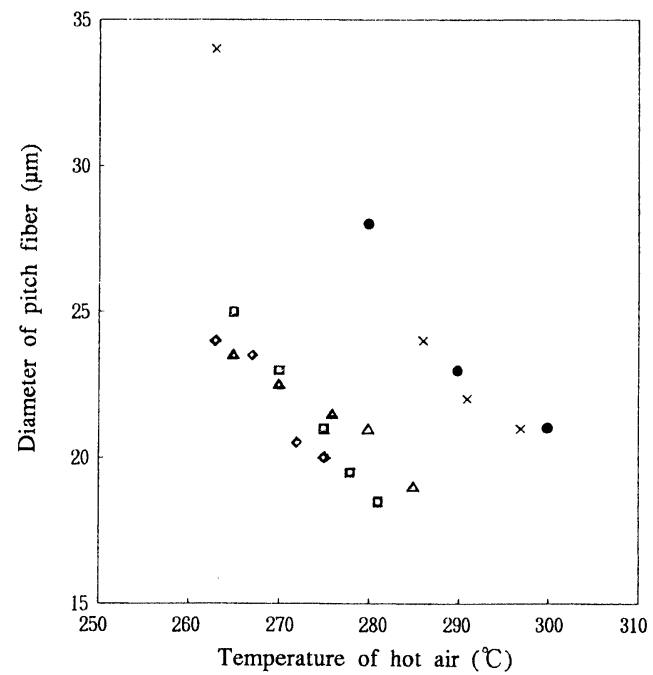

rig.2 Diameter of pitch fiber obtained by various dice. $\left(\mathrm{w}=0.5 \mathrm{~g} / \mathrm{min} \cdot\right.$ hole, temperature of $\left.\mathrm{die}=274^{\circ} \mathrm{C}\right)$

\begin{tabular}{|c|c|c|c|c|}
\hline & die No. & $\mathrm{c}(\mathrm{mm})$ & $\mathrm{d}(\mathrm{mm})$ & $\mathrm{q}(\mathrm{Nl} / \mathrm{min} \cdot$ hole $)$ \\
\hline$x$ & 3 & 2.2 & -0.20 & 6.5 \\
\hline & 4 & 2.2 & +0.20 & 6.5 \\
\hline$\triangle:$ & 4 & 2.2 & +0.20 & 10.0 \\
\hline$\Delta:$ & 1 & 2.5 & -0.15 & 10.0 \\
\hline$\square:$ & 2 & 2.5 & -0.65 & 10.0 \\
\hline
\end{tabular}

$\mathrm{w}=0.167,0.5 \mathrm{~g} / \mathrm{min} \cdot$ hole での熱風の量, 温度を変えた紡 糸実験の結果はFig.3のようになった。各風量において プロットの有る範囲が可紡範囲であった。但し $\mathrm{w}=0.5 \mathrm{~g}$ $/ \mathrm{min} \cdot$ holeでは風量の低い側の実験は省略している。こ の図よりキャピラリー径, ピッチ吐出量により, 採りう る熱風条件が異なることが判る。各風量で図の可紡範囲 の左端はギヤポンプ圧力の上限 (約 $8 \mathrm{MPa}$ )で決まり，右 端は紡糸不安定(ショット発生)となった限界点である。 各条件とも繊維径は熱風量が多いほど，また熱風温度が 高いほど細くなった。 $\mathrm{D}_{\mathrm{n}}=0.2 \mathrm{~mm}, \mathrm{~W}=0.167 \mathrm{~g} / \mathrm{min}$ ・ hole $(\mathrm{a}-1)$ は可紡範囲が広く, 繊維径をもっとも細くでき た。

$\mathrm{D}_{\mathrm{n}}=0.2 \mathrm{~mm}, \mathrm{~W}=0.5 \mathrm{~g} / \mathrm{min} \cdot \operatorname{hole}(\mathrm{a}-2)$ は $0.167 \mathrm{~g} / \mathrm{min}$ ・ holeに較べ低い粘度域で紡糸できたが, 到達緎維径は最

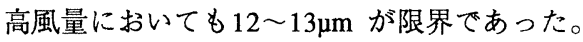

$\mathrm{D}_{\mathrm{n}}=0.3 \mathrm{~mm}$ でW=0.167 $\mathrm{g} / \mathrm{min} \cdot \operatorname{hole}(\mathrm{b}-1)$ では可紡範囲が $\mathrm{D}_{\mathrm{n}}=0.2 \mathrm{~mm}$ に較べて極端に狭くなり, 採りうる温度, 風

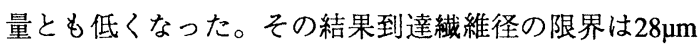
であった。このノズルでは $0.5 \mathrm{~g} / \mathrm{min} \cdot \mathrm{hole}(\mathrm{b}-2)$ の方が可 紡範囲が広く，19umまで紡糸できた。Fig.3に示した実 験結果での繊維径の限界は $8 \mu \mathrm{m}$ 程度であるが, 市販され ているピッチ系の長繊維炭素繊維が $10 \mu \mathrm{m}$ (ピッチ繊維と しては $12 〜 13 \mu \mathrm{m}$ に相当)であることを考えると非常に細 

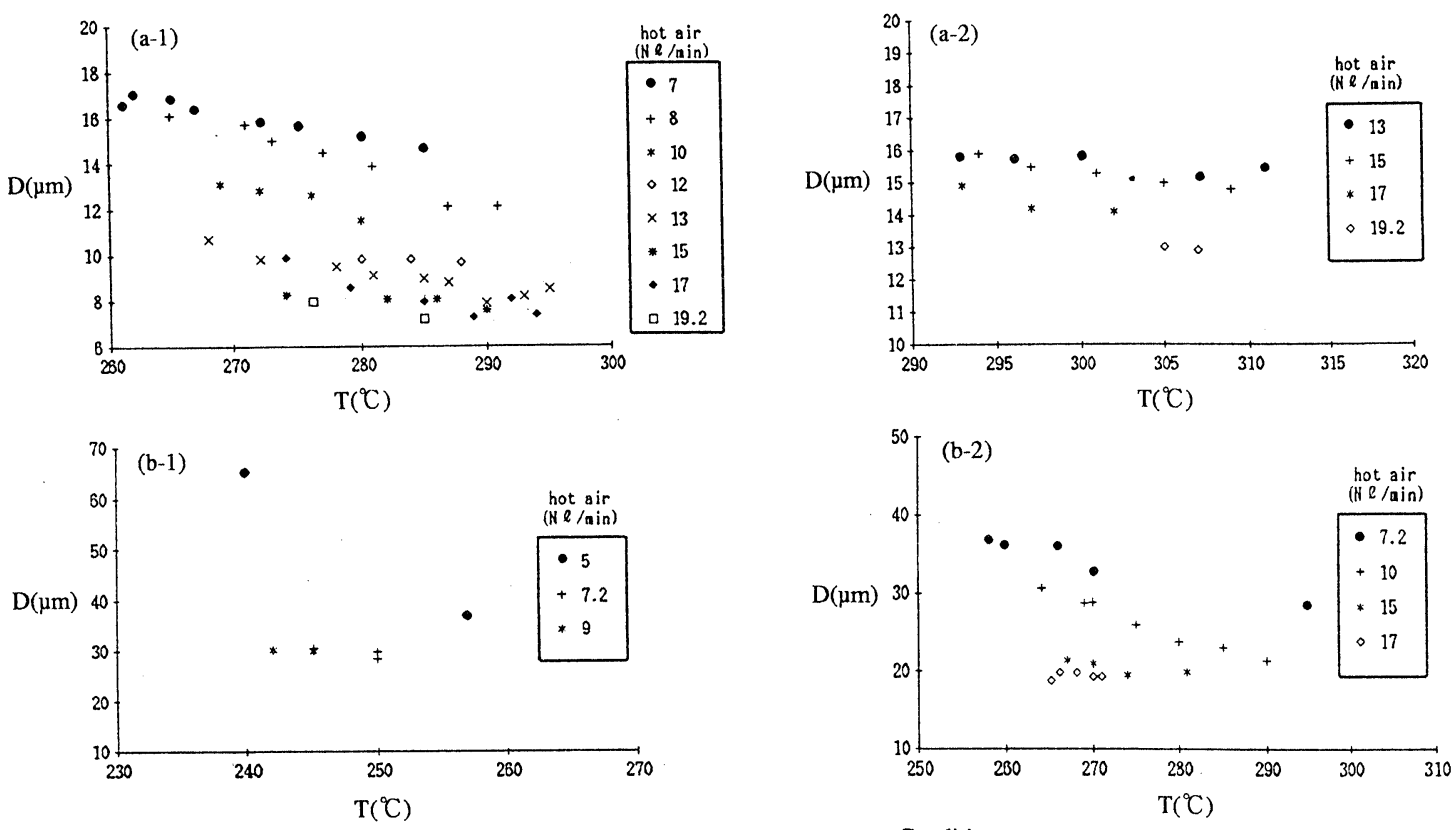

Fig.3 Filament diameter versus spinning conditions.

T ; Temperature of hot air

D ; Diameter of pitch filament (temperature of $\mathrm{die}=276^{\circ} \mathrm{C}$ )

Conditions
\begin{tabular}{|c|c|c|}
\hline & $D_{n}(\mathrm{~mm})$ & $\mathrm{w}(\mathrm{g} / \mathrm{min} \cdot$ hole $)$ \\
\hline $\mathrm{a}-1$ & 0.2 & 0.167 \\
$\mathrm{a}-2$ & 0.2 & 0.500 \\
$\mathrm{~b}-1$ & 0.3 & 0.167 \\
$\mathrm{~b}-2$ & 0.3 & 0.500 \\
\hline
\end{tabular}

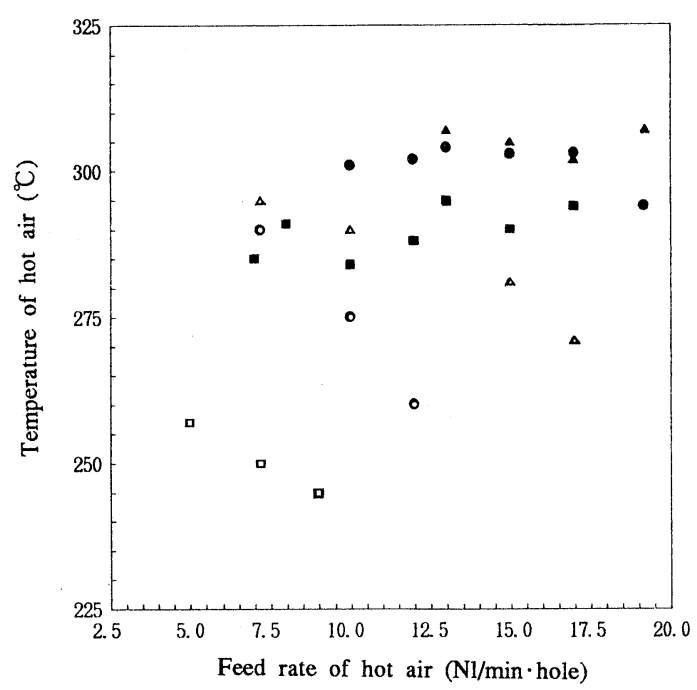

Fig.4 Spinning peak temperature versus feed rate of hot air (temperature of die $=276^{\circ} \mathrm{C}$ ).

\begin{tabular}{cccc}
\hline & $\mathrm{D}_{\mathrm{n}}(\mathrm{mm})$ & (die No.) & $w(\mathrm{~g} / \mathrm{min} \cdot$ hole $)$ \\
\hline$\triangle$ & 0.3 & 1 & 0.500 \\
$\bigcirc \vdots$ & 0.3 & 1 & 0.333 \\
$\square:$ & 0.3 & 1 & 0.167 \\
$\Delta:$ & 0.2 & 5 & 0.500 \\
$\mathrm{D}$ & 0.2 & 5 & 0.333 \\
$\vdots$ & 0.2 & 5 & 0.167 \\
\hline
\end{tabular}

化性がよい。これは紡系粘度が長繊維紡糸法9)に較べて 低いこと，およびノズル直下の冷却雲囲気温度が高いこ とによると考えられる。またノズルあたりの生産性も， 特許などで紹介されている長織維紡系の生産性 $(0.1 \mathrm{~g} / \mathrm{min}$ · hole程度) $)^{1)}$ に較べて優れていることが判る。

$\mathrm{D}_{\mathrm{n}}=0.3 \mathrm{~mm}, 0.2 \mathrm{~mm}$ の両ピッチノズルについて, 紡系 可能であった風量ごとの最高温度を図示すると Fig.4の ようになった。 $\mathrm{D}_{\mathrm{n}}=0.3 \mathrm{~mm}$ は $0.2 \mathrm{~mm}$ に較べ可紡最高温度 が全般に低く，しかも吐出量低下による温度低下幅が大 きい。そして風量が増えるにつれて，最高温度が低下す る傾向を示す。これに対して $0.2 \mathrm{~mm}$ では, やはり吐出量 が低下するにつれて最高温度が低下するが，その落差は 小さく, かつ風量が増えても最高温度はあまり変わらな い。牽引力を変えることによってこのように操業点が変 わることはロール引取法による長繊維紡糸では見られな い現象である。

Fig.5(a),(b)には $D_{\mathrm{n}}=0.3 \mathrm{~mm}, \quad 0.2 \mathrm{~mm}$ の $\mathrm{w}=0.167,0.500$ $\mathrm{g} / \mathrm{min} \cdot$ holeとの組み合わせについて, 各風量における可 紡最高温度とその時のピッチ吐出圧(ギヤポンプ圧力)の 関係を示した。これは各風量の可紡範囲での最低圧損に 

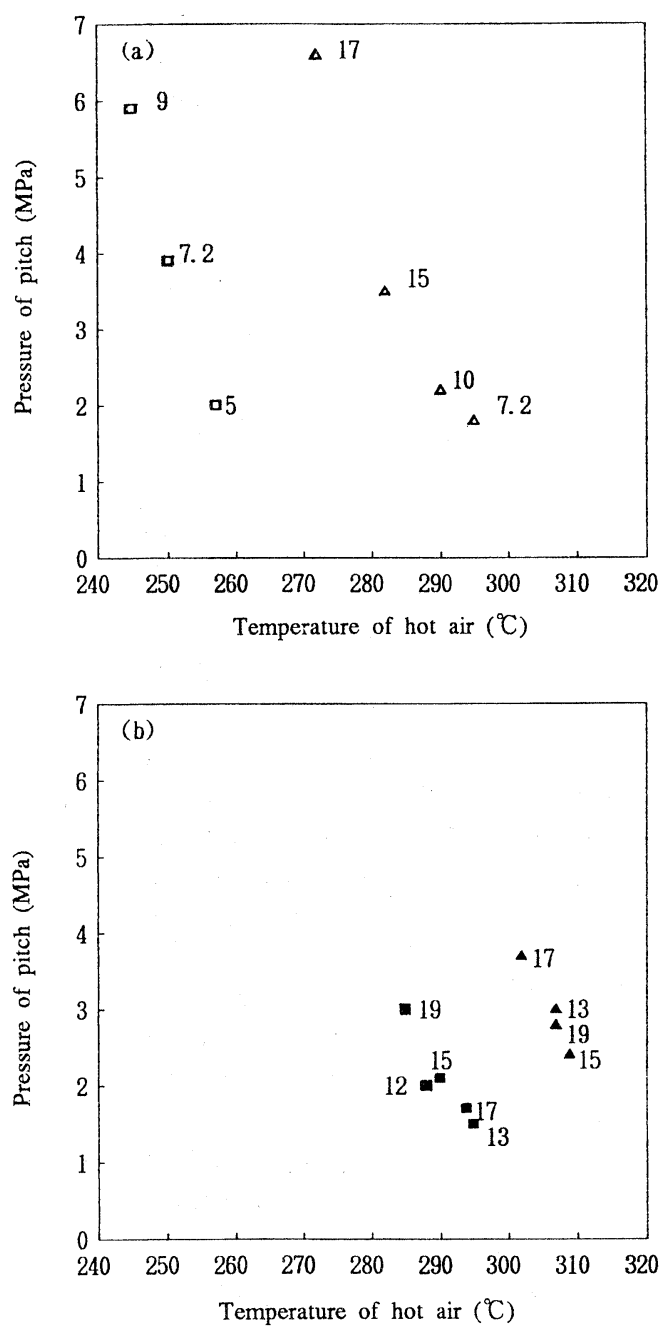

Fig.5 Pressure of picth versus spinnable peak temperature of hot air (temperature of die $276^{\circ} \mathrm{C}$ ). $(9,17 \cdots$ show feed rate of hot air $(\mathrm{Nl} / \mathrm{min} \cdot$ hole $)$.)

(a) $\mathrm{D}_{\mathrm{n}}=0.3 \mathrm{~mm}$ (die No.1)

(b) $\mathrm{D}_{\mathrm{n}}=0.2 \mathrm{~mm}$ (die No.5)
$\triangle, \Delta: \mathrm{w}=0.500(\mathrm{~g} / \mathrm{min} \cdot$ hole $)$
$\square, \square: \mathrm{w}=0.167(\mathrm{~g} / \mathrm{min} \cdot$ hole $)$

相当する (図中添字は熱風量である)。Fig.5(b) $\left(D_{n}=\right.$ $0.2 \mathrm{~mm})$ では各風量について最低圧損がほぼ近いレベルに 集中しているのに対し，Fig.5(a) $\left(D_{n}=0.3 \mathrm{~mm}\right)$ では $w=$ $0.167,0.500 \mathrm{~g} / \mathrm{min} \cdot$ hole とも風量が上がるにつれて圧損 が高くなっている。すなわちキャピラリー径が大きくな ると高風量での高温側の安定域が狭くなることがわか る。

Fig.6は熱風温度に対する繊維径の関係を $\mathrm{D}_{\mathrm{n}}=0.3 \mathrm{~mm}$,

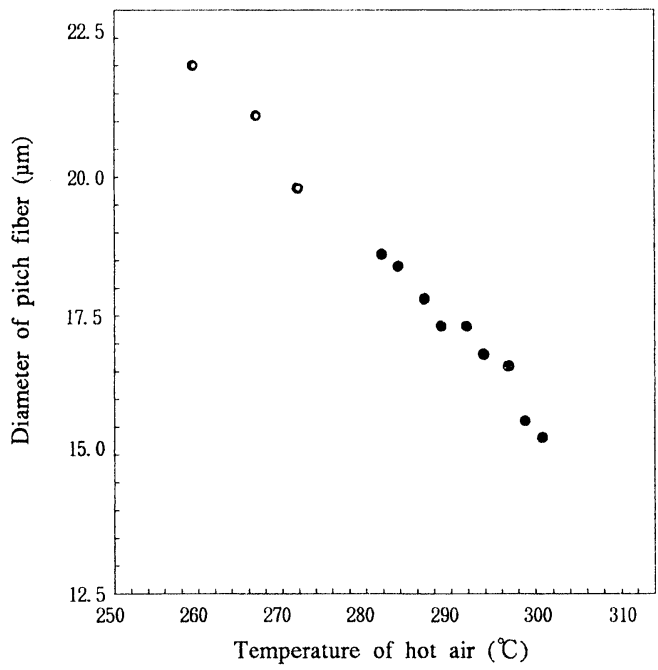

Fig.6 Diameter of picth fiber versus temprature of hot air $(w=0.333 \mathrm{~g} / \mathrm{min} \cdot$ hole, $\mathrm{q}=10 \mathrm{Nl} / \mathrm{min} \cdot$ hole $)$.

: $\mathrm{D}_{\mathrm{n}}=0.3 \mathrm{~mm}$ (die No.1)

: $\mathrm{D}_{\mathrm{n}}=0.2 \mathrm{~mm}$ (die No.5)

$0.2 \mathrm{~mm}$ についてプロットしたものである。緎維径のプ ロットは $\mathrm{D}_{\mathrm{n}}=0.3 \mathrm{~mm}, 0.2 \mathrm{~mm}$ ともほほ同一延長線上に 乗っている。このことから吐出量と風量が等しい場合， 繊維径はキャピラリー径にかかわらず熱風温度で決まる と推定される。したがって $\mathrm{D}_{\mathrm{n}}=0.3 \mathrm{~mm}, 0.2 \mathrm{~mm}$ で到達 緘維径の限界の差はキャピラリー径に応じた採りうる温 度限界の違いによってもたらされると言えよう。

つぎに同一緎維径約 $20 \mu \mathrm{m}$ を与える, 熱風温度と夕゙イ の温度の組み合わはFig.7のようになった。図中に記し た数字はそのときのピッチ吐出圧である。眓より熱風温 度とダイの温度は補完性があることが判る。そして，そ れらのどの組み合わせにおいても，ピッチ吐出圧はほほ 一定であることから，キャピラリー内のピッチの粘度は ほほ等しかったと言える。ダイの温度を固定したFig.6 では, 繊維径はキャピラリー径の寸法にかかわらず, 熱 風量とその温度で決まると見做したが，Fig.7と併せて 考えると, 風量と吐出されるピッチの温度(粘度)によっ て決まるという方が妥当である。

キャピラリー径 $0.2 \mathrm{~mm}$ のピッチノズルを用いた代表的 な紡糸条件でのピッチ繊維径の変動をTable 3に示す。 変動係数は 0.1 程度で大きなばらつきは無いことが判っ た。

\section{4. 考察}

実験結果から瀻維径は熱風の量と温度で決まり，ピッ チノズルのキャピラリー径はそれらの採りうる範囲に関 


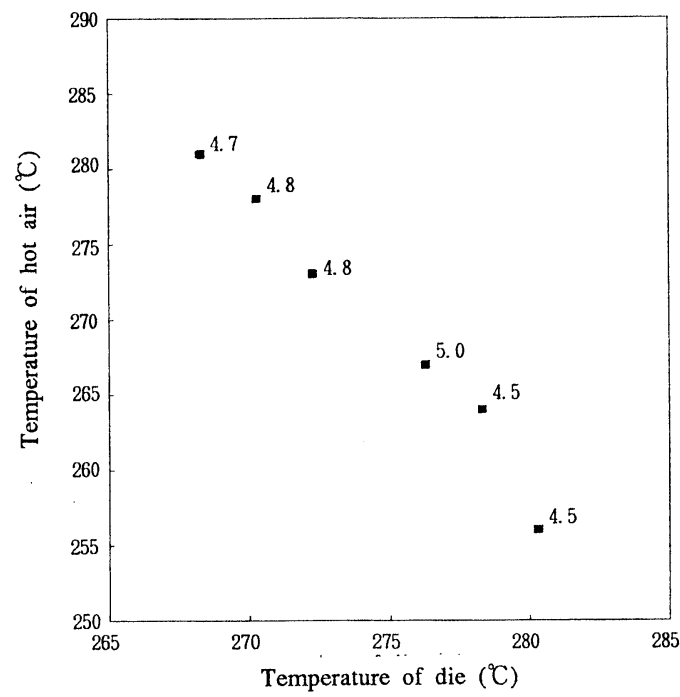

Fig.7 Combination of temperatures of hot air die, givinge the equal diameter of picth fiber. $(\mathrm{w}=0.333 \mathrm{~g} / \mathrm{min} \cdot$ hole, $\mathrm{q}=10 \mathrm{Nl} / \mathrm{min} \cdot$ hole, with die No.5)

(Diameter of picth fibers was $19 \sim 21 \mu \mathrm{m}$ )

Table 3 Variation of filament diameter

\begin{tabular}{cccccc}
\hline $\mathrm{w}(\mathrm{g} / \mathrm{min} \cdot$ hole $)$ & $\mathrm{q}(\mathrm{N} \mathrm{l} / \mathrm{min} \cdot$ hole $)$ & $\mathrm{T}\left({ }^{\circ} \mathrm{C}\right)$ & $\overline{\mathrm{x}}(\mu \mathrm{m})$ & $\sigma(\mu \mathrm{m})$ & $\sigma / \overline{\mathrm{x}}$ \\
\hline 0.167 & 12.0 & $280 \sim 292$ & 9.77 & 0.80 & 0.082 \\
0.333 & 13.0 & $292 \sim 308$ & 13.6 & 1.69 & 0.125 \\
0.500 & 15.0 & $294 \sim 305$ & 15.4 & 1.65 & 0.107 \\
\hline
\end{tabular}

(Spun with die No.5 at die temperature of $276^{\circ} \mathrm{C}$ )

係することが判った。キャピラリー径が細い方がより高 温まで安定であることについては，定性的にはきゅうす 効果によって説明されよう10)。きゅうすから注がれる水 は速度が速いほうが流線が安定する。キャピラリー径が 細い方がピッチの流速が速くなるのでピッチの流線が安 定し，低粘度域まで紡糸できるわけである。より定量的 には, 溶融紡系の低粘度域に扔ける不安定についての毛 管破断の理論から説明できよう。毛管破断の場合の最大 曳糸長は(1)式で与えられる11)。

$$
\mathrm{x}_{\text {cap }}=2 \xi^{-1}\left[\ln \left(\mathrm{R}_{0} / \delta_{0}\right)-\alpha / 3 \eta \mathrm{V}_{0} \xi \mathrm{R}_{0}\right]
$$

ここで $\mathrm{x}_{\text {cap }}$ は最大曳糸長, $\xi$ は変形勾配 $(\mathrm{dlnV} / \mathrm{dx}), \mathbf{R}_{0}$ は吐出流の初期半径すなわち $\mathrm{D}_{\mathrm{n}} / 2, \delta_{0}$ は毛管波の初期振

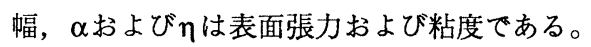

この式によると $\xi$ ，また $\alpha / 3 \eta \mathrm{V}_{0} \xi \mathrm{R}_{0}$ が小さいほど長く 紡糸できる，すなわち紡糸し易い。吐出量が一定のと

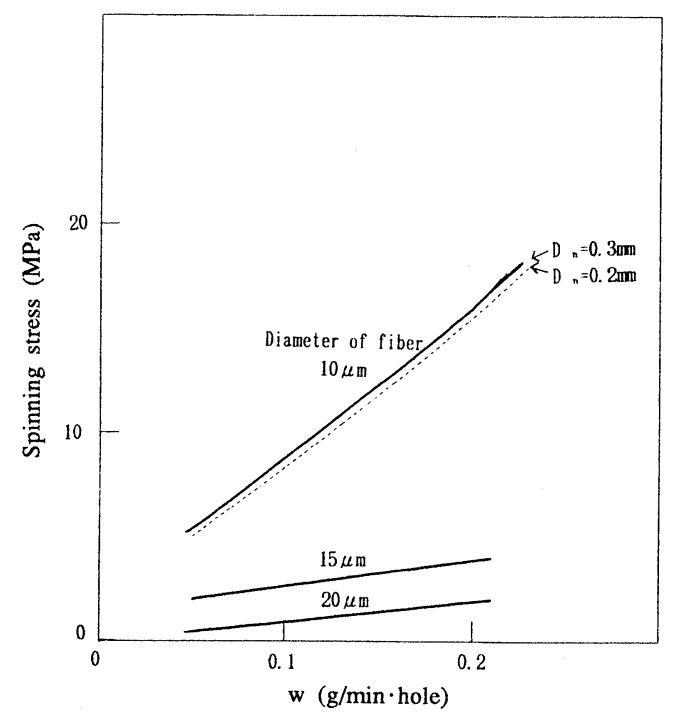

Fig.8 Relation between spinning stress and feed rate of pitch extruded(calculated).

Spaun at $\eta=65 \mathrm{~Pa} \cdot \mathrm{s}$, temperature of atmosphere $=$ $150^{\circ} \mathrm{C}$, distance between die and roll $=0.6 \mathrm{~m}$

き， $\xi, \alpha / 3 \eta V_{0} \xi \mathrm{R}_{0}$ ともキャピラリー径 $\mathrm{D}_{\mathrm{n}}$ が小さいほど 小さくなるので, $\mathrm{D}_{\mathrm{n}}=0.2 \mathrm{~mm}$ の方が $0.3 \mathrm{~mm}$ より紡糸し 易いと言うことができる。他方キャピラリー径が一定の とき，吐出量が多くなると $\mathrm{V}_{0}$ が大きくなり紡糸し易くな る。実験で $\mathrm{D}_{\mathrm{n}}$ が小さいほうが, また吐出量が多いほうが 高温側の可紡範囲が広かったのはこのような理由による と言うことができる。

つぎに目標瀻維径を固定した場合の緎維にかかる張力 をロールの荤引による紡糸をモデルに計算すると Fig.8 のようになった。計算は安田らが紹介しているモデル12) を使用し，ピッチの物性値としては実測值によるつぎの 回帰式を用いた。

$$
\begin{aligned}
& \rho(\mathrm{g} / \mathrm{ml})=1.37-6 \times 10^{-4} \mathrm{~T} \\
& C_{p}\left(\mathrm{cal} / \mathrm{g} \cdot{ }^{\circ} \mathrm{C}\right)=0.24+5 \times 10^{-4} \mathrm{~T} \\
& \eta(\mathrm{pa} \cdot \mathrm{s})=1.320 \times 10^{-19} \exp \left(2.62 \times 10^{4} / T+273\right)
\end{aligned}
$$

ここで $T, \rho, C_{p}, \eta$ はそれぞれ温度 $\left({ }^{\circ} \mathrm{C}\right)$, 密度, 比熱, 剪断粘度である。また伸長粘度は剪断粘度の 3 倍とし た。

Fig.8を見ると吐出量が多くなるにつれてピッチ瀻維 にかかる張力が大きくなり，それも繊維径が小さくなる につれて飛躍的に増加している。固化したピッチ織維の 引張強度はせいぜい50MPaであることを考えると，細い 織維を得るには吐出量を低くせざるを得ないことが判る。 
この図では繊維径 $10 \mu \mathrm{m}$ についてキャピラリー径 $0.2 \mathrm{~mm}$ と $0.3 \mathrm{~mm}$ で張力を示したが，両者にほとんど差 がない。このことからも $0.2 \mathrm{~mm}$ と $0.3 \mathrm{~mm}$ の可紡性の差 は，上に述べたようなキャピラリー吐出部での安定性の 差によることが判る。

\section{5. 結論}

メルトブロー法によるピッチの紡糸技術を研究した。 ロール引取法と異なり, 率引力(風量)やピッチ吐出量に よって紡系に適する温度範囲が大きく変わることが判っ た。細く曳くにはピッチのノズルからの吐出が高温域で 安定することが重要であり，そのためには細いピッチノ ズル径を選ぶ必要がある。キャピラリー径 $0.2 \mathrm{mm \Phi のノ}$ ズルでは吐出量 $0.167 \mathrm{~g} / \mathrm{min} \cdot$ hole 能で，ロール引取法を凌ぐ成績を示した。また繊維径の 変動係数は $10 \%$ 程度であった。

メルトブロー法はロール引取法に較べてつぎのような 特徵が有るのでコストの低い短繊維の製造用として今後 の発展が期待される。

1)繊維径が細くできる。

2)ノズルあたりの生産性が高い。

3)糸切れしても太い系が混入することがない。

4)糸切れ後ロール掛け作業が要らない。

\section{謝辞}

本研究を行うにあたり種々のご支援を頂いた新日鉄設 備技術センター山中広明氏, 深町邦男氏に厚く御礼申し 上げる。

\section{文献}

1) 例えば

岩下輝雄, 荒井 豊, 砂子洋文, 特開平 2-242917.

2) 宮守 保, 亀山厳, 阿部武雄, 特開昭62-33823.

3) ウイリアム・ソーラン, ジョン・ニューマン, クリ フォード・ワード，特開昭58-132079.

4) 池田得三，渥美昭洋，特開昭62-90320.

5) 田畑博文, 高松明男, 特開平 1-221520.

6) V. A. Wente, I.E.C. 48 (1956) 1342.

7) D. T. Lohkamp, USP 3825379 (1974).

8) R. R. Buntin, J. P. Keller and J. W. Harding, USP 3978185 (1976).

9) 小山清人, 青木勝博, 石塚 修, 繊維学会誌 44 (1988) 59.

10) マーカス ライナー, レオロジーの基礎 p.29, コロナ社.

11) H. F. Marks, S. M. Atlas and E. Cernia 編, 石川欣 造, 温品謙二訳, 化学瀻維I (1970) p.13, 丸善.

12) 安田 浩, 石原英昭, 染川博生, 繊維学会誌 34 (1978) 20. 